\title{
KARAKTERISASI POPULASI IKAN PUTAK (Notopterus notopterus) MENGGUNAKAN ANALISIS KERAGAMAN FENOTIPIK DAN DAERAH 16 SRNA DNA MITOKONDRIA
}

\author{
Arif Wibowo'), Mas Tri Djoko Sunarno'), Subagja'), dan Taufiq Hidayah'1) \\ 1) Peneliti pada Balai Riset Perikanan Perairan Umum, Mariana-Palembang \\ 2) Peneliti pada Pusat Riset Perikanan Tangkap, Ancol-Jakarta
}

Teregistrasi I tanggal: 17 Oktober 2008; Diterima setelah perbaikan tanggal: 28 Januari 2009; Disetujui terbit tanggal: 20 Pebruari 2009

\begin{abstract}
ABSTRAK
Penelitian ini dilakukan pada tahun 2006 di Sungai Ogan, Sungai Kelekar (anak Sungai Musi, Sumatera Selatan), perairan di Pulau Bangka serta Kota Bangun dan Tanah Ulu (Sungai Mahakam, Kalimantan Timur). Tujuannya adalah untuk menganalisis karakterisasi populasi ikan putak (Notopterus notopterus) dari berbagai habitat berdasarkan pada karakter fenotipik dan genetik serta untuk menentukan karakter morfologi sebagai pembeda utama, mendeterminasi jarak kemiripan antar populasi ikan putak dan untuk menganalisis apakah perbedaan morfologi antar populasi tersebut hanya sekedar fenotipik plastisity atau memiliki dasar evolusi yang signifikan. Dari lokasi pengambilan contoh yang ditentukan secara sengaja (purposive sampling) berhasil dikoleksi 49 spesimen untuk pengukuran morfometrik dan meristik yang berasal dari lima lokasi berbeda dan tujuh spesimen dari dua populasi untuk marka molekuler. Pengukuran biometrik dilakukan pada 35 karakter morfologi bentuk badan pada bagian sisi sebelah kiri tubuh ikan. Data biometrik dianalisis dengan Analisis Deskriminan, menggunakan Software Statistica 6.0, sedangkan data genetik menggunakan Metode Restriction Fragment Length Polymorphism (RFLP) pada mitokondria (mtDNA), menggunakan primer 16S rRNA, hasilnya dianalis secara manual kualitatif. Hasil penelitian menunjukkan bahwa berdasarkan pada analisis karakter morfologi, populasi ikan putak yang terdapat di Sungai Ogan, Sungai Kelekar, perairan di Bangka, dan Sungai Mahakam (Kota Bangun dan Tanah Ulu) merupakan populasi yang terpisah. Karakter pembeda utama antar kelompok populasi tersebut adalah Snouth Length (SL), Isthmus Length (IL), dan Adipose Length (AL). Populasi ikan putak yang berada di Pulau Kalimantan (Tanah Ulu dan Kota Bangun) memiliki jarak kemiripan yang cukup jauh dengan populasi di Pulau Sumatera (Ogan, Kelekar dan Bangka). Terlihat jelas bahwa pola isolasi dikarenakan oleh barrier alam. Perbedaan antar populasi ikan putak tidak hanya merupakan plastisity fenotipik, namun juga telah memiliki dasar evolusi.
\end{abstract}

KATAKUNCI: putak, Notopterus notopterus, karakterisasi, morfometrik, meristik, 16S rRNA mtDNA

ABSTRACT: Population characteristic of the putak (Notopterus notopterus) using fenotipic diversity analysis and 16sRNA region mitochondria DNA. By: Arif Wibowo, Mas Tri Djoko Sunarno, Subagja, and Taufiq Hidayah

This reseach was conducted at 2006 in the rivers of Ogan and Kelekar (segment of Musi River, South Sumatera), waters in Bangka Island, and Kota Bangun, and Tanah Ulu (segment of Mahakam River, East Kalimantan). This study was to reveal population characteristic of putak (Notopterus notopterus) from different habitats based on its characters of fenotipic and genetic, and to determine the most discriminate morphological characters, to determine similiarty distance among the putak population and to analyze whether morphological differences among those populations are just phenotipic plastisity or it has evolution significantly. Of sampling locations selected using purposive sampling were got 49 specimens for measurement of morphometric and meristic originated from five different locations and seven specimens for mtDNA analysis originated from two different populations. Biometric measurement was conducted at 35 morphological characters on the leftside of the fish body. Restriction Fragment Length Polymorphism (RLFP) Method was employed for mt DNA analysis using 16S rRNA marker. Biometric datum was subject to Discriminant Analysis using Statistica 6.0 package, since mtDNA was analyzed by manual qualitative. The results on morphological analysis showed that the putak originated from Ogan River, Kelekar, inland waters of Bangka Island, Kota Bangun, and Tanah Ulu were separated population. Snouth Length (SL), Isthmus Length (IL), and Adipose Length (AL) are the most discriminate morphological characters. Population of the putak from Kalimantan Island (Tanah Ulu and Kota Bangun) had wider similarity distance compared to from that Sumatera population (Ogan River, Kelekar River, and Bangka Island). It was clearly shown that 
the putak population among different islands was isolated by natural barrier. Morphological difference of the putak was not only caused by fenotipic, but also by evolution significance.

\section{KEYWORDS: $\quad$ putak, Notopterus notopterus, population, morphometric, meristic, 16S rRNA mt DNA}

\section{PENDAHULUAN}

Ikan putak (Notopterus notopterus) adalah ikan asli Indonesia yang dilindungi berdasarkan pada Peraturan Pemerintah No.7 Tahun 1999 tentang Jenis-Jenis Hayati Indonesia yang Dilindungi. Keberadaan ikan ini di Indonesia terkait dengan sejarah biogeografi. Menurut de Beaufort (1951), pada Zaman Pleistocene terdapat suatu sistem sungai yang mengalir di antara Benua Asia dan Paparan Sunda yang membuat ikan menjadi terdistribusi spasial. Pada zaman itu terjadi pemisahan benua termasuk terpisahnya Paparan Sunda dari benua induk (Asia). Selanjutnya, Paparan Sunda yang berada dalam wilayah Indonesia membentuk Pulau Sumatera, Kalimantan, dan Jawa dan memisahkan berbagai jenis flora dan fauna, termasuk ikan putak.

Kondisi populasi yang terisolasi selama jutaan tahun, ketiadaan aliran gen, seleksi lingkungan, dan kondisi demografi masing-masing populasi ikan putak diduga menghasilkan keragaman dan perbedaan morfologi dan genetik baik intraspesifik maupun interspesifik. Karakterisasi populasi ikan putak menjadi sesuatu yang penting karena dua hal, yaitu pertama Indonesia telah meratifikasi Konvensi Keanekaragaman Hayati (Convention on Biological Diversity); dan kedua ikan putak dikategorikan sebagai ikan yang dilindungi berdasarkan pada Peraturan Pemerintah No.7 Tahun 1999. Hal ini berarti bahwa populasi ikan putak di alam sudah sedikit. Pengelolaannya di masa depan akan diarahkan melalui konservasi insitu, restocking, dan domestikasi yang membutuhkan data karakterisasi populasi.

Karakterisasi populasi dapat dilakukan melalui pengamatan fenotipik (morfometrik dan meristik) sebagai bentuk interaksinya dengan lingkungan dan melalui marka molekular (genetik) (Tanning, 1952; Jawad, 2001; Turan et al., 2004). Salah satu marka molekular yang digunakan adalah zona $16 s R N A$ dan DNA mitokondria. RNA ribosomal merupakan molekul yang terevolusi antar organisme hidup. Molekul ini bersifat homolog secara fungsional maupun evolusinya pada organisme berbeda dan merupakan molekul yang strukturnya terkonservasi; ukuran sekuennya cukup besar untuk dibandingkan sehingga bersifat signifikan secara statistik (Sullivan et al., 2000).

Penelitian ini bertujuan untuk menganalisis karakterisasi populasi ikan putak (Notopterus notopterus) dari berbagai habitat berdasarkan pada karakter fenotipik dan genetiknya dan menentukan karakter morfologinya sebagai pembeda utama, mendeterminasi jarak kemiripannya antar populasi dan menganalisis apakah perbedaan morfologi antara populasi tersebut hanya sekedar fenotipik plastisity atau memiliki dasar evolusi yang signifikan.

\section{BAHAN DAN METODE}

\section{Pengambilan Contoh Ikan}

Penentuan lokasi untuk mendapatkan contoh spesimen ikan putak (Notopterus notopterus) dilakukan secara purposive sampling pada lima perairan yang ada ikan putaknya dan memiliki kisaran geografis yang luas (Gambar 1). Ikan contoh diperoleh dari hasil tangkapan nelayan dan pedagang pengumpul. Contoh ikan untuk pengamatan fenotifik (morfometrik dan meristik) berjumlah 49 spesimen yang berasal dari lima lokasi dan untuk marka molekuler sebanyak tujuh spesimen dari dua lokasi.

Untuk setiap spesimen, sebagian jaringan permukaan kulit sirip ekor (berukuran $1 \times 1 \mathrm{~cm}^{2}$ ) diambil dengan menggunakan disecting set yang telah disterilisasi terlebih dahulu, dan direndam dalam vial tube yang berisi alkohol $75 \%$ dan diberi label kode asal spesimen, dan kemudian disimpan dalam lemari pendingin. Permukaan kulit adalah bagian yang aktif melakukan metabolisme yang memerlukan ATP yang tinggi, sehingga kandungan mitokondrianya banyak (Thorpe, 1984). Untuk carcass, dikeluarkan isi perutnya, disuntik alkohol $75 \%$ dan ditandai dengan kode lokasi asal spesimen dengan menggunakan dymo machine; contohnya P.KLK 001. Contoh yang sudah ditandai, selanjutnya diawetkan dengan cara direndam dalam larutan alkohol $75 \%$ untuk identifikasi lebih jauh di laboratorium.

\section{Karakter Morfologi (Fenotipik)}

Pengukuran biometrik yang dilakukan adalah morfometrik dan meristik. Morfometrik adalah perbandingan ukuran relatif bagian-bagian tubuh ikan, sedangkan meristik adalah bagian yang dapat dihitung dari ikan yang merupakan jumlah bagian-bagian tubuh ikan, misal jumlah duri pada perut.

Morfometrik spesimen diukur dengan digital caliper yang memiliki ketelitian $0,10 \mathrm{~mm}$, sedangkan 


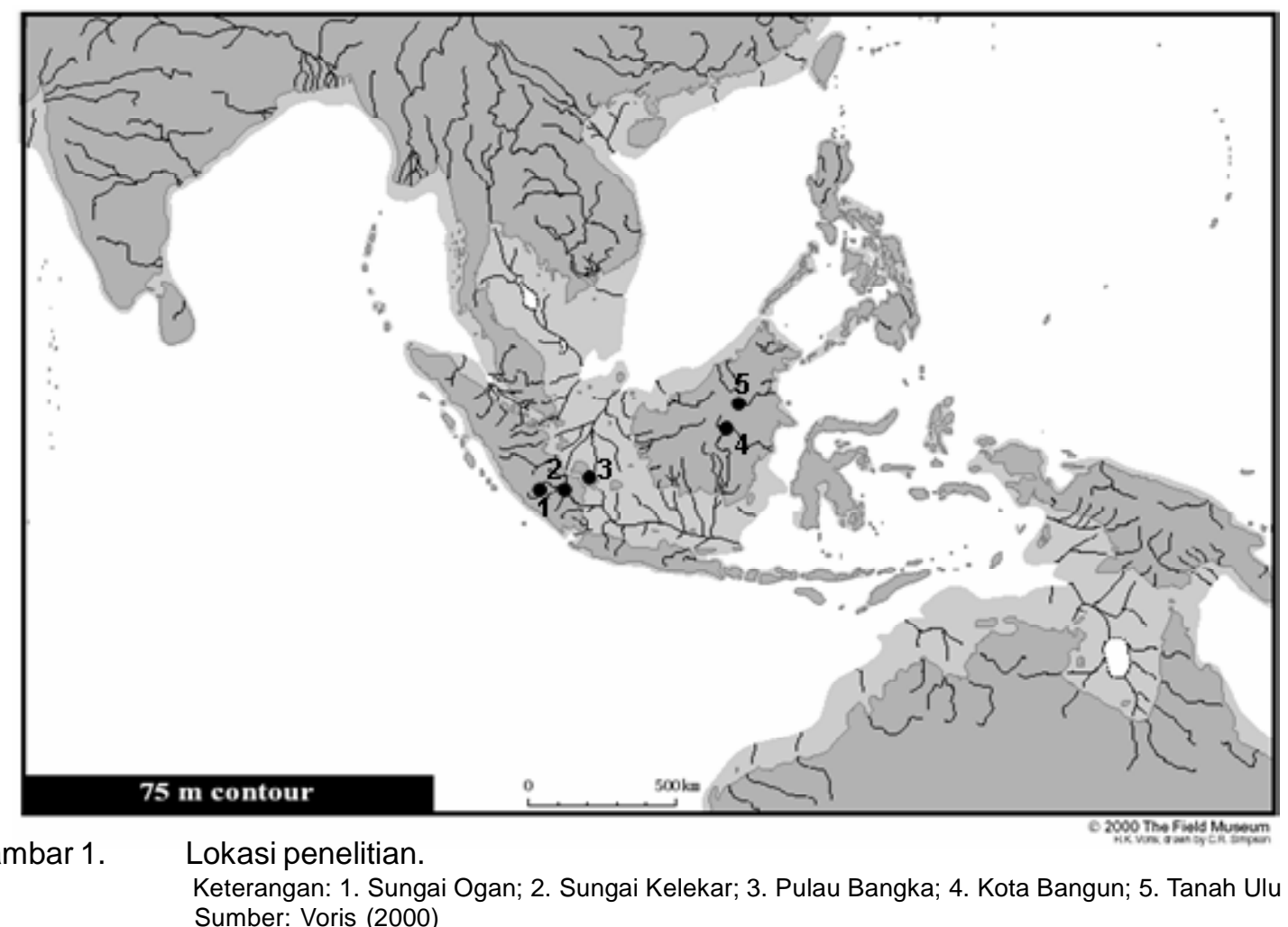

Figure 1. Reasearch locations.

Remarks: 1. Ogan River; 2. Kelekar River; 3. Bangka Island; 4. Kota Bangun; 5. Tanah Ulu Source: Voris (2000)

meristik dihitung dengan penghitungan secara manual di bawah kaca pembesar. Pengukuran karakter morfometrik dan meristik ikan putak dilakukan pada 35 karakter morfologi bentuk badan (Gambar 2) pada bagian sisi sebelah kiri tubuh ikan.

Data morfometrik dan meristik yang diperoleh, selanjutnya dianalisis multivariate menggunakan Discriminant Analysis (Fisher, 1936). Dalam studi ini, teknik analisis deskriminan digunakan untuk melihat tingkat kesamaan antar populasi ikan putak dari berbagai lokasi dan mengidentifikasi secara benar karakter morfometrik dan meristik pembeda utamanya. Selanjutnya, menggambar jarak genetik melalui analisis kluster berdasarkan pada penghitungan mahalobis distance. Sebelum analisis dilakukan, seluruh data morfometrik semua spesimen contoh distandarisasi dalam bentuk \% SL dan ditrasformasi ke dalam log $(x+1)$. Pengolahan data menggunakan paket program Statistica versi 6.0.

\section{Marka Molekular (16 sRNA DNA mt-DNA)}

Analisis genetik menggunakan metode Restriction Fragment Length Polymorphism (RFLP)-PCR pada DNA mitokondria dengan tahapan-tahapan pengerjaan sebagai berikut: DNA ikan diekstraksi dari potongan sirip ekor dengan menggunakan kit Wizard genome DNA purification (promega), 5 - $10 \mathrm{mg}$ potongan sirip ikan dimasukkan ke dalam tabung $1,5 \mathrm{~mL}$ yang telah berisi $500 \mu \mathrm{L}$ larutan lisis DNA + 120 larutan $0,5 \mathrm{M}$ EDTA pH 8,0. Kemudian ditambahkan $10 \mu \mathrm{g}$ per $\mathrm{mL}$ protein kinase dan diinkubasi pada suhu $55^{\circ} \mathrm{C}$ selama tiga jam. Sebanyak tiga $\mu \mathrm{L}$ larutan Rnase ditambahkan ke dalam campuran tersebut, kemudian diinkubasi pada suhu $37^{\circ} \mathrm{C}$ selama 30 menit. Setelah didinginkan pada suhu kamar, ditambahkan ke dalam larutan protein precipitation $200 \mu \mathrm{L}$ dan disimpan dalam es selam 5 menit. Kemudian disentrifus pada kecepatan 10.000 rpm selama 10 menit. Lapisan supernatan diambil dan dimasukkan ke dalam tabung baru, dan ditambahkan $600 \mu \mathrm{L}$ larutan propanol dan divortex sampai terlihat endapan putih. DNA diendapkan dengan cara mensentrifus campuran tersebut pada kecepatan $10.000 \mathrm{rpm}$ selama 10 menit, kemudian larutan di atasnya dibuang dan DNA dikeringkan pada suhu ruangan. Setelah kering, ditambahkan $50-100$ $\mu \mathrm{L}$ Tris EDTA buffer dan disimpan pada suhu $4^{\circ} \mathrm{C}$ sebelum digunakan pada tahap selanjutnya.

Primer yang digunakan untuk mengamplikasi sequence mitokondria adalah 16sarRNA primer-5* CGC CTG TTT AAC AAAAAC AT.16sbr-3* CCG GTT TGAACT CAG ATCAT GT (Palumbi, 1996). Amplifikasi 

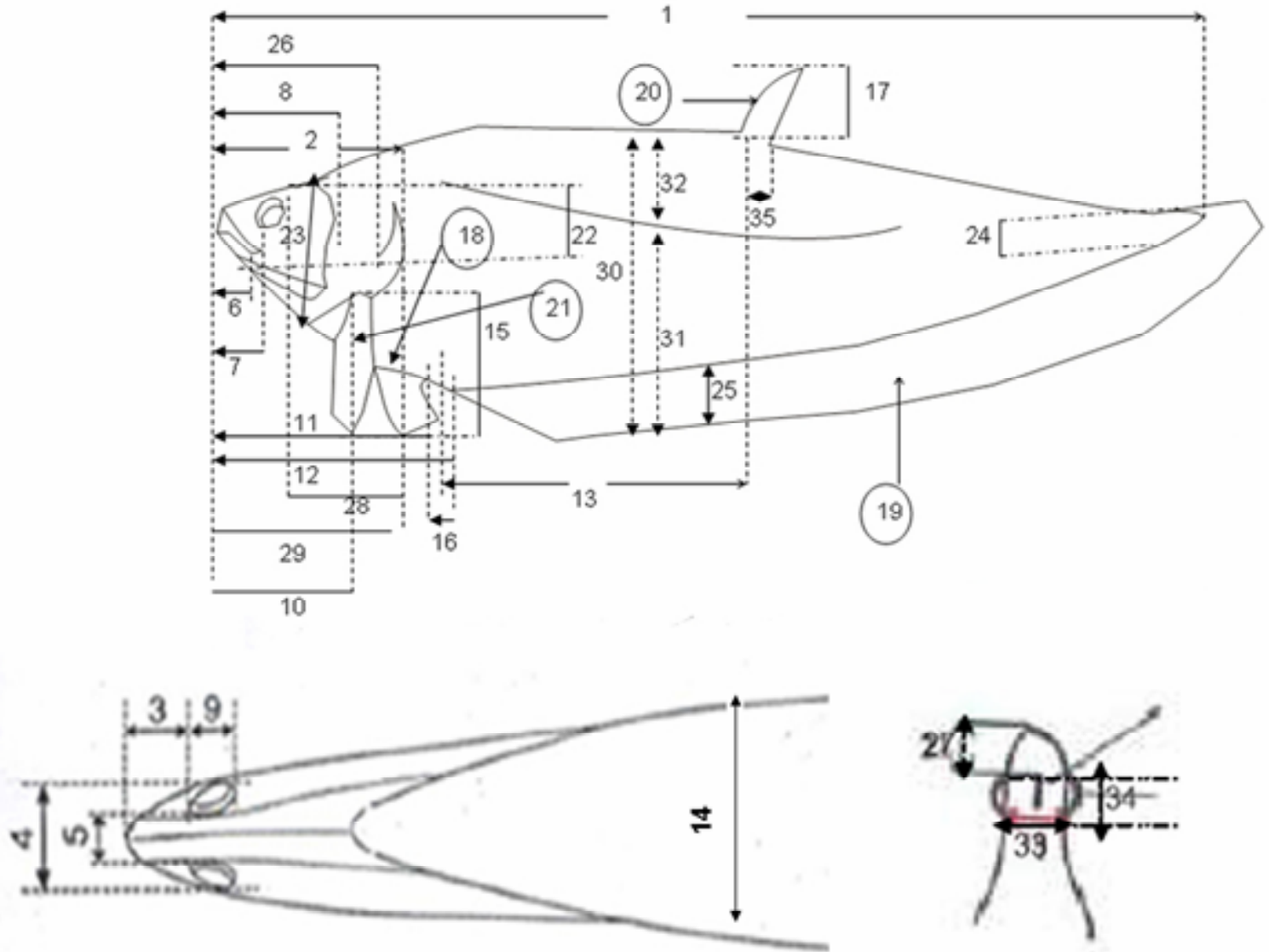

Karakter:

1. Standard Length

2. Distance to second operculum (DSO)

3. Snouth length (SNL)

4. Head Width (HD)

5. Interorbital width (IOW)

6. Upper jaw mouth (UJM)

7. Lower Jaw Mouth (LJM)

8. Pectoral length

9. Eye diameter (ED)

10. Prepectoral fin length (PPFL)

11. Prepelfic length (PPL)

12. Pre-anal length (PAL)
13. Distance first anal to dorsal (DFD)
14. Body width (BW)
15. Pectoral fin length (PFL)
16. Pelvic fin length (PEFL)
17. Dorsal fin length (DFL)
18. Number of ventral spines (NVS)
19. Number of anal fin length (NAFL)
20. Number of pectoral fin (NPF)
21. Number of dorsal fin (NDF)
22. Head depth (HD)
23. Peduncle length (PL)
24. Caudal peduncle depth (CPD)

25. Anal fin width (AFW)

26. Adipose length $(A L)$

27. Distance snouth to isthmus (DSI)

28. Pastocular length ( $P A L)$

29. Head length $(\mathrm{HL})$

30. Body depth (BD)

31. Distanc Lineral Lateralis to lower body (DLB)

32. Distance LL to upper body (DLU)

33. Mouth width (MW)

34. Isthmus length (ISL)

35. Dorsal spine width (DSW)

Gambar 2. Pengamatan karakter fenotipik ikan putak (N. notopterus). Figure 2. Observation of fenotipe characteristics of the putak (N.notopterus).

menggunakan alat PCR merek Applied Biosystem dengan komposisi reaksi yang terdiri atas $10 \mu \mathrm{g}, 10$ pmol setiap primer, dan pure tag DNA (promega) dengan total volume $25 \mu \mathrm{L}$. Siklus PCR yang digunakan dalam aplifikasi adalah satu siklus denaturasi pada suhu $95^{\circ} \mathrm{C}$ selama dua menit. 35 siklus penggandaan yang terdiri atas $95^{\circ} \mathrm{C}$ selama 1 menit, $55^{\circ} \mathrm{C}$ selama 1 menit dan $72^{\circ} \mathrm{C}$ selama 2,5 menit. Selanjutnya, satu siklus terakhir pada suhu $72^{\circ} \mathrm{C}$ selama 10 menit. Hasil PCR dilihat secara elekforesis dengan menggunakan gel agarose dua sampai tiga persen dalam Tris Acid EDTA buffer dan dilihat gambar dengan polaroid.

DNA sasaran yang teraplifikasi, selanjutnya direstriksi dengan menggunakan enam enzim restriksi. Enam enzim restriksi tersebut adalah Taq 1, Ndell, Alu I, HaellI, Hind III, dan Rsal untuk mendapatkan gambaran keragaman genetik yang ditunjukan dari pola-pola pemotongan yang polimorf. Sequence mtDNA yang didapat direstriksi dengan menggunakan endonuklease sesuai dengan prosedur 
perusahaan. Hasil restriksi kemudian dipisahkan secara elekforesis dengan menggunakan gel agarose 2 - 3\% dalam Tris Boric EDTA bufferdan diamati dengan illuminator (UV) serta dicetak gambar dengan polaroid.

Susunan haplotipe ikan putak pada berbagai lokasi penelitian dari masing-masing enzim restriksi dikumpulkan sebagai komposit haplotipe dan dianalisis manual kualitatif.

\section{HASIL DAN BAHASAN}

\section{Karakter Morfologi (Fenotipik)}

\section{Analisis morfometrik}

Ikan putak (N.notopterus) yang diperoleh di lokasi penelitian terlihat memiliki sebaran morfometrik yang beragam (Tabel 1), sekaligus menggambaran karakteristik ikan putak yang diamati. Ada kecenderungan bahwa lokasi dengan jumlah contoh yang lebih banyak memiliki standard erroryang lebih kecil. Pengujian dengan Wilk's Lamda mengindikasikan adanya perbedaan antar empat populasi ketika karakter morfometrik dibandingkan dengan rata-rata analisis deskriminan (Tabel 2).

Analisis stepwise mengungkapkan 24 dari 31 karakter morfometrik secara nyata memberikan kontribusi pada deskriminan multivarian dari empat populasi ikan putak yang diamati (Tabel 3). Gambaran rata-rata dan standar deviasi ke-24 karakter morfometrik tersebut dapat dilihat pada Gambar 3.Tingkat klasifikasi benar yang diduga dari prosedur validasi silang dari 24 karakter fungsi deskriminan mencapai 100\% (Tabel 4).

Pemisahan lengkap dari nilai centroid untuk masing-masing kelompok dikonfirmasi oleh plot dari dua variat kanonical (Gambar 4a) yang menjelaskan keragaman 61,41 dan $24,2 \%$ dari keseluruhan variasi (Tabel 3).

Tabel 1. Karakteristik ikan putak (N. notopterus) di lokasi cuplikan Table 1. The putak ( $\boldsymbol{N}$. notopterus) characteristic in sampling locations

\begin{tabular}{lccc}
\hline \multirow{2}{*}{ Kelompok/Group } & \multicolumn{2}{c}{ Analisis morfometrik/Morphometric analysis } & \multirow{2}{*}{ SL range } \\
\cline { 2 - 3 } & $\mathbf{n}$ & mean SL \pm SE & $166,20-250,23$ \\
\hline Ogan & 9 & $206,31 \pm 8,31$ & $230,20-261,84$ \\
Kota Bangun & 2 & $246,02 \pm 15,82$ & $136-219,5$ \\
Bangka & 8 & $186,20 \pm 11,92$ & $225-273$ \\
Tanah Ulu & 31 & $246,68 \pm 2,15$ & \\
\hline
\end{tabular}

Tabel2. Hasil pengujian Wilk's Lambda untuk melihat perbedaan populasi Table 2. Wilk's Lambda test result refering to population difference

\begin{tabular}{|c|c|c|c|c|c|c|c|c|}
\hline \multirow{2}{*}{$\begin{array}{l}\text { Fungsi/ } \\
\text { Function }\end{array}$} & \multicolumn{4}{|c|}{$\begin{array}{l}\text { Analisis morfometrik/ } \\
\text { Morphometric analysis }\end{array}$} & \multicolumn{4}{|c|}{$\begin{array}{l}\text { Analisis meristik/ } \\
\text { Meristic analysis }\end{array}$} \\
\hline & Wilks' & Chi-Sqr. & df & p-level & Wilks' & Chi-Sqr. & df & p-level \\
\hline 0 & 0,005383 & $180,2478^{* * *}$ & 69 & 0,000000 & 0,206287 & $69,45350^{\star \star *}$ & 12 & 0,000000 \\
\hline 1 & 0,059702 & $97,2342^{* * *}$ & 44 & 0,000007 & 0,737803 & $13,37948^{*}$ & 6 & 0,037390 \\
\hline 2 & 0,297013 & $41,8823^{*}$ & 21 & 0,004353 & 0,963669 & $1,62832^{\text {ns }}$ & 2 & 0,443010 \\
\hline
\end{tabular}

Gambar 4a memperlihatkan bahwa berdasarkan pada karakter morfometrik, ke-empat populasi terpisah sempurna. Nilai potensi indeks (Tabel 3) mengindikasikan bahwa karakter ISL, SNL, dan AL adalah karakter utama pembeda keseluruhan deskriminan. Ketiga karakter morfometrik tersebut merupakan karakter yang terdapat di kepala dan hal ini diduga berhubungan dengan makanan. Menurut Gosoline (1996), kepala yang besar sesuai untuk memangsa mangsa yang besar dan keras - makanan utama ikan putak adalah udang dan ikan kecil.
Populasi ikan putak dari Tanah Ulu secara jelas terplotkan ke sebelah kanan dari scatterplot, sementara ketiga populasi ikan putak yang lainnya (Bangka, Ogan, dan Kota Bangun) terplotkan ke sebelah kiri. Untuk itu, fungsi deskriminan pertama terutama membedakan antara populasi ikan putak dari Tanah Ulu dengan tempat lainnya. Fungsi kedua menyediakan deskriminasi antara populasi Ogan dengan populasi Kota Bangun, Bangka, dan Tanah Ulu. Populasi Ogan terplotkan di sebelah atas scatterplot, sementara populasi yang lainnya berada 
di bagian bawah fungsi deskriminan kedua. Namun demikian, fungsi kanonicalpertama (CV1) lebih jelas dalam membedakan populasi ikan putak dibandingkan fungsi kanonikal kedua (CV2) dengan nilai masingmasing 61,4 dan 24,2\% (Tabel 3). Berdasarkan fakta tersebut dapat disimpulkan bahwa semakin besar karakter SNL, ISL, dan AL, semakin besar individu tersebut termasuk ke dalam populasi Tanah Ulu. Hal ini berlaku sebaliknya untuk tiga populasi ikan putak lainnya.

Dendogram pada Gambar 5a yang dibuat dari analisis kluster berdasarkan pada karakter morfometrik mengkonfirmasi terjadinya isolasi, karena ada perbedaan jarak geografis yang jauh. Terlihat bahwa populasi ikan putak yang berada di Sungai Mahakam (Tanah Ulu dan Kota Bangun) terpisah dengan populasi di Pulau Bangka dan Sungai Ogan. Diduga bahwa pemisahan populasi terjadi di Sungai Mahakam yaitu antara populasi ikan putak yang berada di Tanah Ulu dengan Kota Bangun. Menurut Turan et al. (2004), tingkat isolasi yang cukup lama dengan wilayah geografis yang terbatas dapat menghasilkan perbedaan morfologi yang nyata antar populasi dalam spesies yang sama, karena tidak adanya aliran gen di antara populasi tersebut. Selain aliran gen, seleksi alam juga memberikan kontribusi terhadap perbedaan morfologi antar populasi ikan (Roni \& Quinn, 1995; Jawad, 2001).

Tabel 3. Indeks potensi untuk karakter yang masuk dalam model fungsi deskriminan diestimasi terpisah untuk karakter morfometrik dan meristik. Loading deskriminan untuk semua karakter yang diamati dan persentase variasi yang dijelaskan oleh 2 variabel kanonikal

Table 3. Potency indexs for variable in model of discriminance function estimated separatly for morphometric and meristic characters. Loading descriminance for all observed characters and percentage variation explained by 2 conical variabels

\begin{tabular}{|c|c|c|c|}
\hline Karakter/Character & Indeks potensi/Potency index & \multicolumn{2}{|c|}{ Loading deskriminan/Discriminant loading } \\
\hline \multicolumn{2}{|c|}{ Morfometrik/Morphometric } & CV1 & CV2 \\
\hline IOW & 0,753089 & $-0,94635$ & 0,81774 \\
\hline $\mathrm{HL}$ & 0,584075 & $-2,36092$ & $-1,62770$ \\
\hline DSI & 0,714857 & 0,65254 & 0,76594 \\
\hline PEFL & 0,670336 & 0,91981 & $-0,11321$ \\
\hline PTL & 0,606887 & 1,30212 & 0,62136 \\
\hline DLU & 0,825013 & $-0,32358$ & 0,42883 \\
\hline DSW & 0,595357 & 1,08683 & 0,05890 \\
\hline PPL & 0,663451 & $-0,95702$ & $-0,11851$ \\
\hline $\mathrm{HD}$ & 0,660969 & $-0,78945$ & 0,44001 \\
\hline SNL & 0,426640 & 1,84913 & 0,52057 \\
\hline ISL & 0,391075 & 1,90792 & 0,48711 \\
\hline CPD & 0,831048 & 0,38535 & 0,45074 \\
\hline AFW & 0,758150 & 0,78076 & $-0,05492$ \\
\hline DFL & 0,712621 & $-0,46127$ & $-0,71972$ \\
\hline $\mathrm{AL}$ & 0,513644 & 1,33168 & 1,70109 \\
\hline $\mathrm{BD}$ & 0,610481 & $-1,34153$ & $-0,75190$ \\
\hline $\mathrm{PL}$ & 0,629078 & 1,36249 & 1,88460 \\
\hline DFD & 0,559379 & $-1,27137$ & $-0,90112$ \\
\hline PASL & 0,544130 & 1,88925 & 0,26259 \\
\hline PAL & 0,647206 & $-1,30224$ & $-0,37937$ \\
\hline LJM & 0,651671 & 1,31623 & 0,14293 \\
\hline DLB & 0,698483 & 1,68836 & 0,32315 \\
\hline DSO & 0,799435 & $-1,05894$ & $-0,65110$ \\
\hline$\%$ varian & & 61,41 & 24,2 \\
\hline Meristik/Meristic & & CV1 & CV2 \\
\hline NDF & 0,360893 & $-1,02114$ & $-0,241093$ \\
\hline NPF & 0,654393 & $-0,60920$ & 0,648378 \\
\hline NAFL & 0,810694 & 0,35602 & $-0,688522$ \\
\hline$\%$ varian & & 88,22 & 14,08 \\
\hline
\end{tabular}




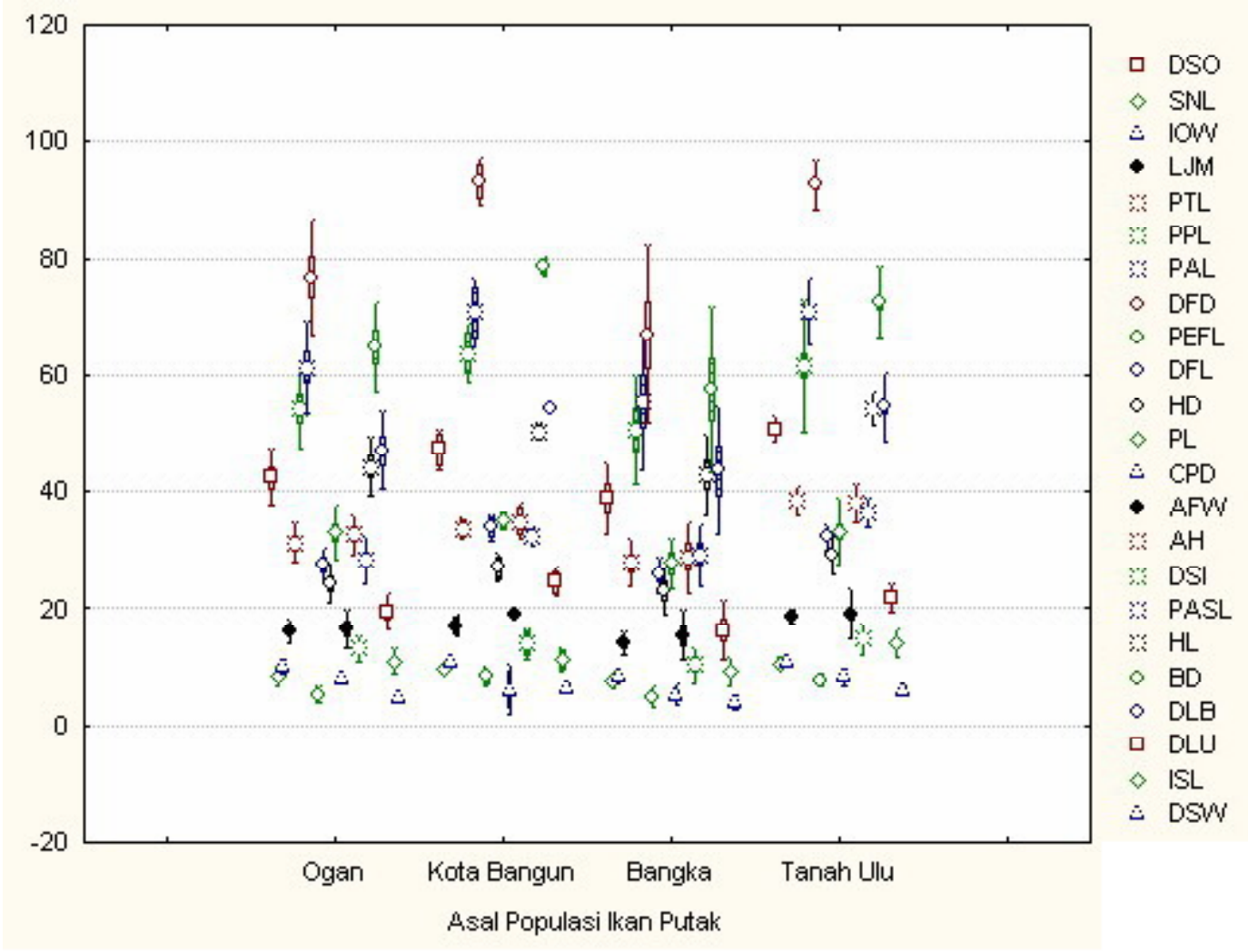

Gambar 3. Nilai rata-rata dan standar deviasi dari karakter morfometrik yang masuk dalam model deskriminan.

Figure 3. Average value and deviation standard of morphometric characters inferred in discriminant model.

Tabel 4. Hasil klasifikasi analisis deskriminan stepwise untuk karakter morfometrik dan meristik Table 4. Classification result of stepwise discriminant analysis for morphometric a nd meristic characters

\begin{tabular}{|c|c|c|c|c|c|c|c|}
\hline \multirow[t]{2}{*}{$\begin{array}{l}\text { Kelompok/ } \\
\text { Group }\end{array}$} & \multirow[t]{2}{*}{$\mathbf{n}$} & \multirow[t]{2}{*}{$\begin{array}{r}\text { Persen benar/ } \\
\text { validity }(\%)\end{array}$} & \multicolumn{5}{|c|}{$\begin{array}{c}\text { Klasifikasi kelompok populasi ikan putak } \\
\text { (Notopterus notopterus)/ } \\
\text { Group classification of putak fish } \\
\text { (Notopterus notopterus) population }\end{array}$} \\
\hline & & & Ogan & Kota Bangun & Bangka & Tanah Ulu & Kelekar \\
\hline \multicolumn{8}{|c|}{ Morfometrik/Morphometric } \\
\hline Ogan & 8 & 100 & 8 & 0 & 0 & 0 & \\
\hline Kota Bangun & 2 & 100 & 0 & 2 & 0 & 0 & \\
\hline Bangka & 8 & 100 & 0 & 0 & 8 & 0 & \\
\hline Tanah Ulu & 31 & 100 & 0 & 0 & 0 & 31 & \\
\hline Total & 49 & 100 & 8 & 2 & 8 & 31 & \\
\hline \multicolumn{8}{|l|}{ Meristik/Meristic } \\
\hline Kelekar & 2 & 50 & 0 & 0 & 1 & 0 & 1 \\
\hline Ogan & 7 & 57,14 & 4 & 0 & 2 & 1 & 0 \\
\hline Kota Bangun & 2 & 0 & 0 & 0 & 2 & 0 & 0 \\
\hline Bangka & 8 & 87,5 & 0 & 0 & 7 & 1 & 0 \\
\hline Tanah Ulu & 30 & 93,33 & 2 & 0 & 0 & 28 & 0 \\
\hline Total & 49 & 81,63 & 6 & 0 & 12 & 30 & 1 \\
\hline
\end{tabular}




\section{Analisis meristik}

Seperti halnya pada karakter morfometrik, pengujian Wilk's Lamda mengindikasikan adanya perbedaan antar kelima kelompok populasi ikan putak yang diamati ketika dibandingkan dengan rata-rata analisis deskriminan, namun dalam kasus ini hanya dua fungsi kanonikal yang nyata (Tabel 2).

Analisis stepwise mengungkapkan adanya tiga dari empat karakter morfometrik yang secara nyata memberikan kontribusi pada deskriminan multivariat dari empat populasi ikan putak yang diamati (Tabel 3). Gambaran rata-rata dan standar deviasi ke-3 karakter morfometrik tersebut dapat dilihat pada Gambar 6.

Tingkat klasifikasi benar yang diduga dari prosedur validasi silang dari tiga karakter fungsi deskriminan berkisar antara 0 - 93,33\% (Tabel 4). Tabel 4 juga mengindikasikan bahwa karakteristik spesifik dari populasi ikan putak yang diamati diduga disebabkan oleh faktor lingkungan yang memberikan kontribusi yang cukup besar. Hal ini terlihat ketika populasi ikan putak yang berasal dari Kota Bangun masuk ke dalam kelompok Bangka, walaupun kedua kelompok populasi tersebut terpisah dalam jarak jauh.

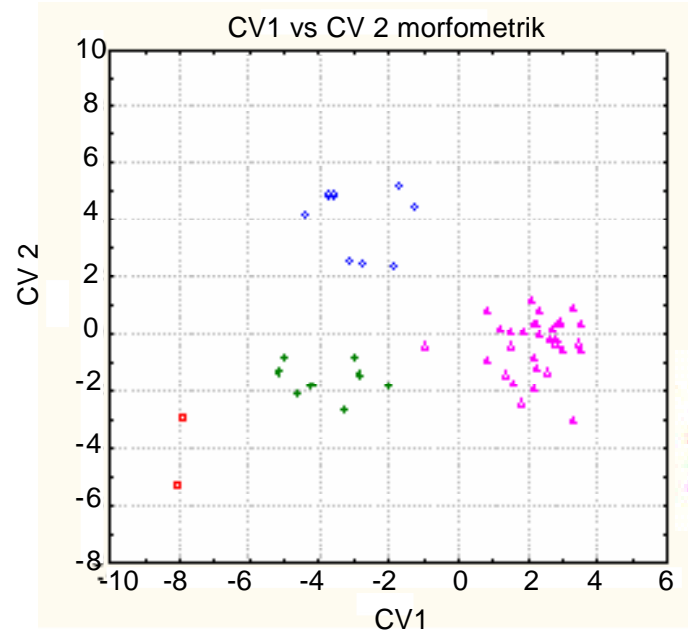

(a)

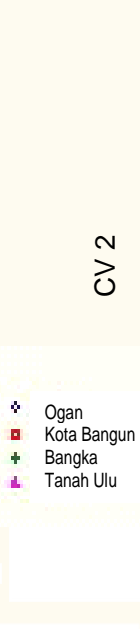

$\stackrel{2}{d}$

Gambar 4. Plot individual dan group centroid pada canonical variable 1 dan 2 untuk 4 sampai dengan 5 populasi ikan putak berdasarkan pada karakter morfometrik (a) dan meristik (b).

Figure 4. Individual plot and centroid group of canonical variable 1 and 2 for 4 to 5 of the putak populations based on morphometric and meristic characters.

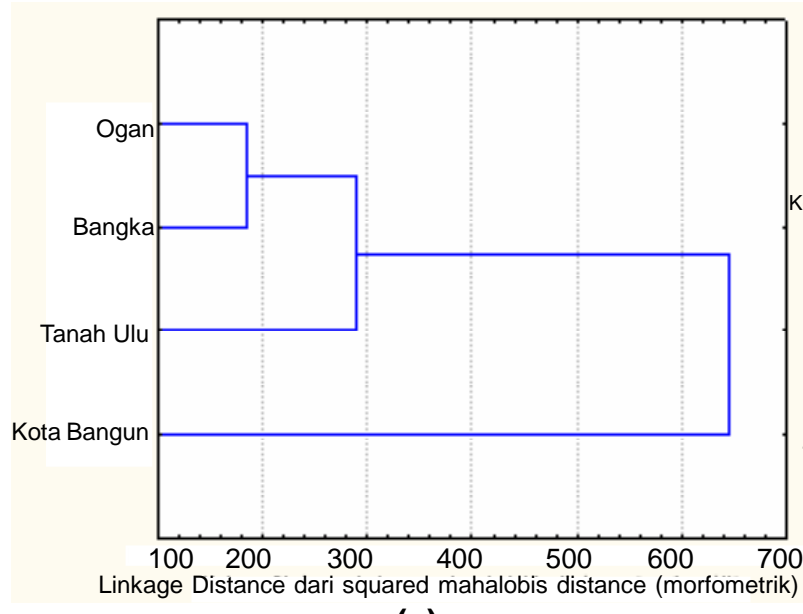

(a)

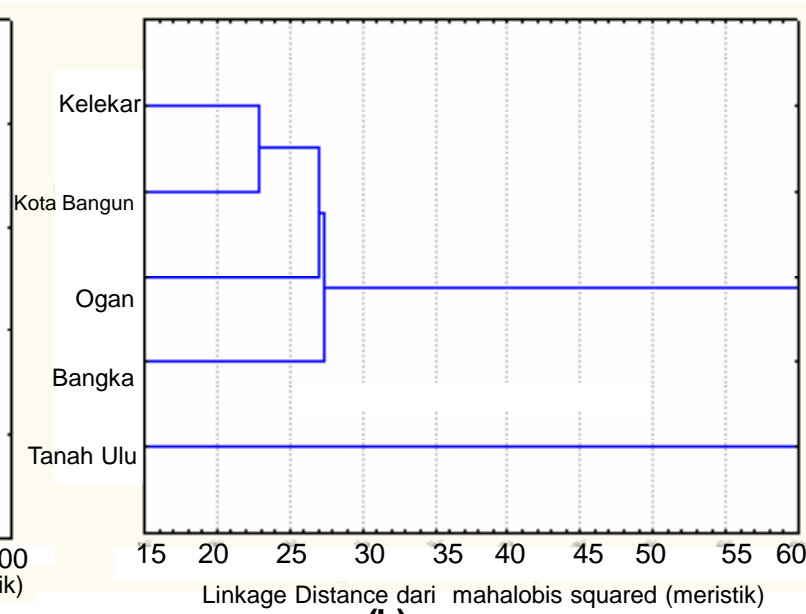

(b)

Gambar 5. Dendogram dibuat berdasarkan pada analisis Cluster Mahalobis Distance untuk karakter morfometrik (a) dan meristik (b).

Figure 5. Dendogram made based on Cluster analysis of Mahalobis Distance for morphometric (a) and meristic (b) characters. 
Pemisahan dari nilai centroid untuk masing-masing kelompok dikonfirmasi oleh plot dari dua variat kanonical (Gambar 4b) yang menjelaskan bahwa keragamannya adalah sebesar 88,22 dan $14,08 \%$ dari keseluruhan variasi (Tabel 3). Gambar 4b memperlihatkan bahwa berdasarkan pada karakter meristik, kelima populasi ikan putak memiliki pola tersebar. Nilai potensi indeks (Tabel 3) mengindikasikan bahwa karakter NDF dan NPF
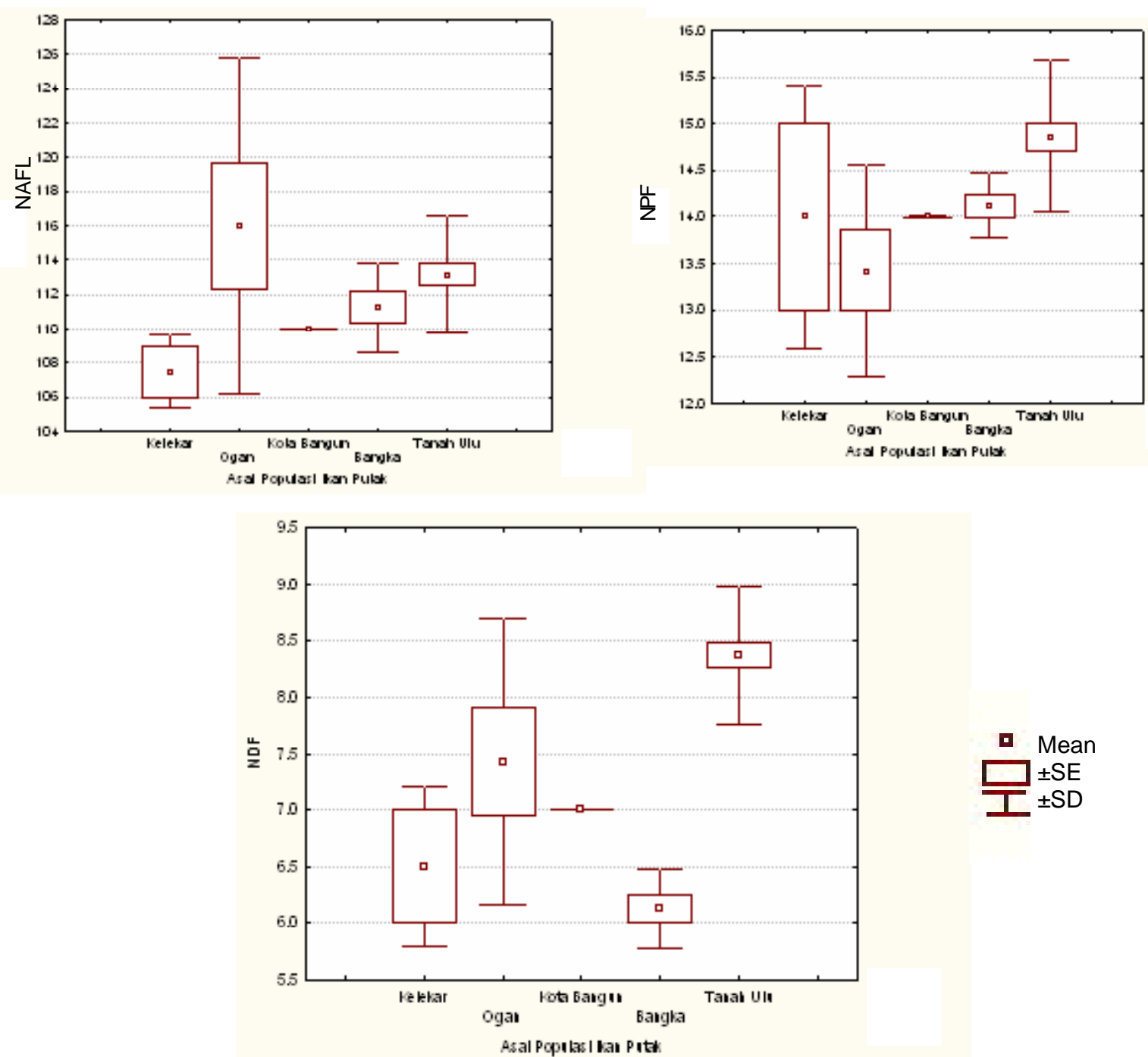

adalah dua karakter meristik yang menjadi karakter utama pembeda keseluruhan deskriminan.

Dendogram pada Gambar 5b yang dibuat dari analisis kluster berdasarkan pada karakter meristik mengkonfirmasikan terjadinya isolasi pada populasi ikan putak yang berasal dari Tanah Ulu, karena adanya perbedaan jarak geografis yang jauh, namun dalam hal ini tidak berlaku untuk populasi ikan putak di Kota Bangun. Populasi yang berasal dari kelompok

Gambar 6. Karakter meristik pada kelima populasi ikan putak; a. NAFL; b. NPF; dan c. NDF. Figure 6. Meristic characters on the fitth putak population; a. NAFL; b. NPF; dan c. NDF.

Sumatera (Bangka, Ogan, dan Kelekar) memiliki kemiripan yang dekat.

\section{Interpretasi hasil analisis morfometrik dan meristik}

Hasil pengelompokkan dengan karakter morfometrik memperlihatkan pola yang memisah yang dapat membedakan antar populasi ikan putak dari lokasi asal yang berbeda. Sementara pengelompokan dengan menggunakan karakter meristik memperlihatkan pola yang menyebar. Penghitungan meristik ditentukan selama kurun waktu yang singkat selama tahap awal perkembangan dan karakteristik yang paling lama tampak selama ontogeni adalah yang paling labil (Barlow, 1961). Ada 
kecenderungan hubungan yang baik antara suhu lingkungan yang lebih tinggi dengan jumlah meristik yang lebih besar (Tanning, 1952). Sepertinya jumlah elemen ditentukan oleh tingkat perkembangan, tingkat periode perkembangan yang lebih lama menghasilkan jumlah meristik yang lebih banyak (Barlow, 1961).

Karakter morfometrik terbukti lebih cocok sebagai pembeda populasi ikan putak. Menurut Barlow (1961), perbedaan ini disebabkan oleh fakta bahwa variasi dalam bentuk yang biasanya berhubungan dengan sebab genetik, sementara karakter meristik lebih tergantung pada fluktuasi lingkungan (Gambar 4b).

\section{Analisis DNA Ikan Putak}

\section{DNA total}

Ada tujuh total DNA ikan putak yang diisolasi dari dua populasi, yaitu Ogan (enam contoh) dan Kelekar (satu contoh). Semua total DNA hasil isolasi dielektroforesis pada gel agarose untuk menguji keberadaan dan kuantitas total DNA yang diperoleh sebelum dilakukan aplifikasi PCR. Total DNA hasil isolasi tersebut digunakan sebagai DNA cetakan aplifikasi daerah 16 sRNA dengan menggunakan teknik PCR. Hasil isolasi total DNA dapat dilihat Gambar 7.

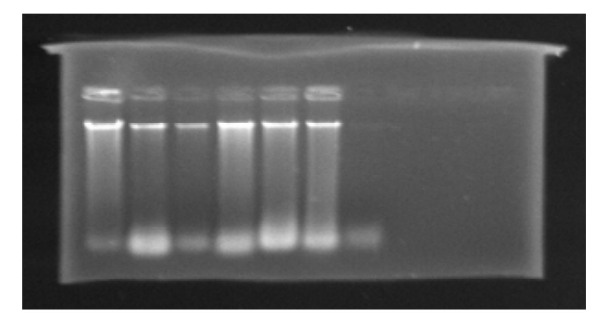

Gambar 7. Total DNA ikan putak setelah dimigrasikan dalam gel agarose $2 \%$ pada tegangan 90 Volt selama 30 menit.

Figure 7. DNA total of the putak after migrated to agarose gel $2 \%$ on 90 Volt for 30 minutes.

\section{Amplifikasi daerah 16sRNA}

Berdasarkan pada runtutan genom utuh mitokondria, fragmen DNA ikan putak memiliki ukuran 660 - 750 bp. Tampilan optimal fragmen hasil aplifikasi pasangan primer tersebut dengan menggunakan mesin PCR Genomex pada kondisi annealing $45^{\circ} \mathrm{C}$ selama satu menit dapat dilihat pada Gambar 8.

\section{Pemotongan dan variasi genetik ikan putak}

Dari enam restriksi enzim yang digunakan yaitu Taq 1, Ndell, Alu I, HaellI, Hind III, dan Rsal hanya empat yang memotong fragmen daerah mtDNA yang diaplifikasi. Keempat enzim tersebut adalah Taq I, Ndell, Alul, dan Hae III. Enzim Taq 1 mempunyai hasil pemotongan yang polymorfik berupa dua tipe restriksi, sedangkan tiga enzim lainnya mempunyai pola pemotongan yang monomorfik. Tipe haplotype ikan putak dari Sungai Ogan berbeda dengan dari Kelekar. Ikan putak Sungai Ogan didominansi oleh haplotype \#2 (Gambar 9), sedangkan haplotype \#3 (Gambar 10) terdapat pada contoh dari Kelekar.

Dari enam contoh ikan putak Sungai Ogan yang diamati tidak terdapat variasi genetik atau variasi genetiknya homogen (semua contoh memiliki tipe pemotongan yang sama), sedangkan untuk ikan putak dari Sungai Kelekar tidak dapat dilihat karena jumlah contohnya hanya satu. Namun demikian, dapat dilihat bahwa telah terjadi pemisahan populasi antara ikan putak yang berada di Sungai Ogan dan Kelekar walaupun masih dalam satu sungai (Sungai Musi). 


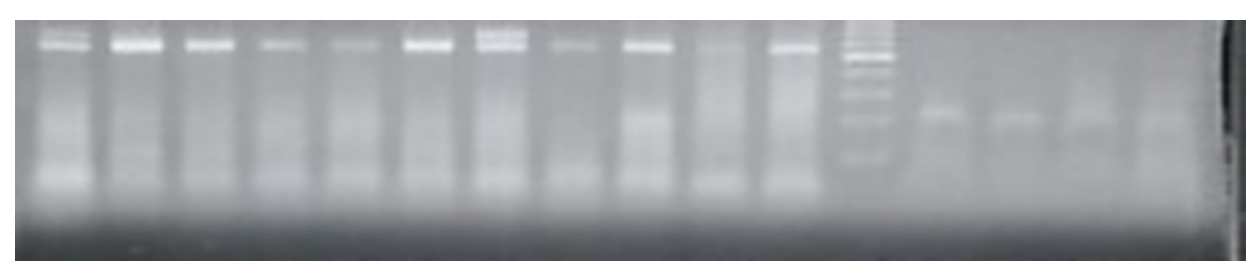

Gambar 8. Hasil aplifikasi daerah 16sRNA dengan menggunakan pasangan primer sar dan sbr setelah dimigrasikan kedalam gel agarose $2 \%$ pada tegangan 90 Volt selama 45 menit.

Figure 8. Aplification result of 16sRNA using a pair of sar dan sbr primer after migrated to agarose gel $2 \%$ on 90 Volt for 30 minutes.

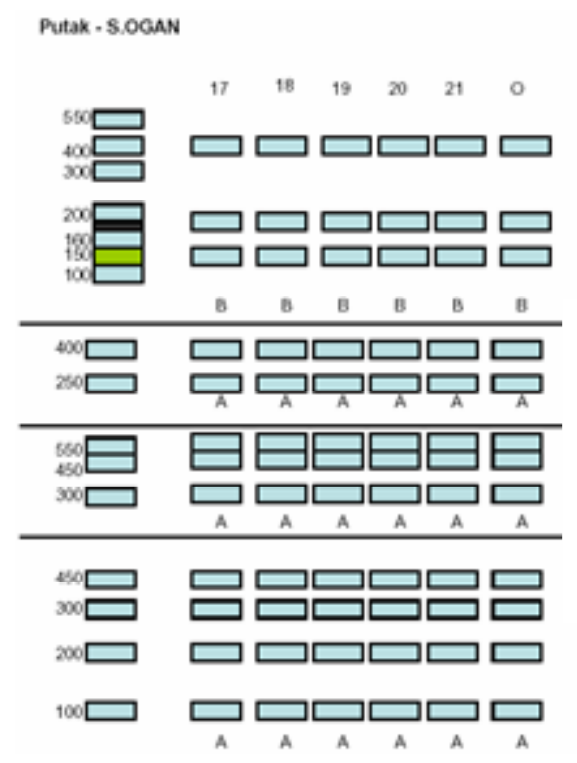

Gambar 9. $\quad$ Tipe haplotype ikan putak (N. notopterus) Sungai Ogan.

Figure 9. Haplotype type of the putak (N. notopterus) from Ogan River.

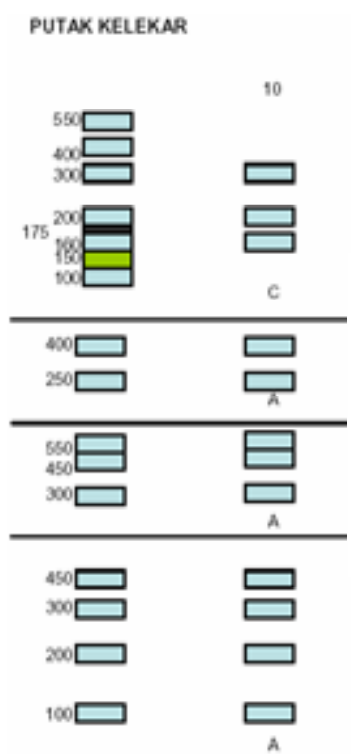

Gambar 10. Tipe haplotype ikan putak (N. notopterus) Sungai Kelekar.

Figure 10. Haplotype type of the putak (N. notopterus) from Kelekar River. 


\section{KESIMPULAN}

Berdasarkan pada analisis karakter morfologi, populasi ikan putak (Notopterus notopterus) yang terdapat di Sungai Ogan, Kelekar, Bangka, Kota Bangun, dan Tanah Ulu merupakan populasi yang terpisah. Karakter pembeda utama antar kelompok populasi tersebut adalah Snouth Length, Isthmus Length, dan Adipose Length. Populasi ikan putak yang berada di Kalimantan (Tanah Ulu dan Kota Bangun) memiliki jarak kemiripan yang cukup jauh dengan populasi di Sumatera (Ogan, Kelekar, dan Bangka). Perbedaan antar populasi ikan putak tidak hanya merupakan plastisitas fenotipik, namun telah memiliki dasar evolusi.

\section{PERSANTUNAN}

Kegiatan dari hasil riset karakteristik habitat dan keragaman jenis ikan belida, T. A. 2006 di Balai Riset Perikanan Perairan Umum, Mariana-Palembang.

\section{DAFTAR PUSTAKA}

Barlow, G. W. 1961. Causes and significance of morphological variation in fishes. System Zoology. 10: 105-117.

de Beaufort, L. F. 1951. Zoogeography of Land and Inland Waters. Sidgwick and Jackson Ltd. London. $208 \mathrm{pp}$.

Fisher, R. A. 1936. The use of multiple measurements in taxonomic problems. The Annals of Eugenics. 7: $179-188$.

Gosline, W. A. 1996. Structures associated with feeding in three broad mouthed, bentic fish groups. Environment Biology Fishes. 47: 399-405.
Jawad, L. A. 2001. Variation in meristic characters of a tilapian fish, Tilapia zilli (gervais, 1848) from the inland Water bodies in Libya. Acta Ichthyology Piscat. 31 (1): 159-164.

Palumbi, S. R. 1996. Nucleic Acids. II. The polymerase chain reaction. In Molecular Systematics (ed. D. M. Hillis, C. Moritz, \& B. K. Mable). p. 205-247. Sunderland, M. A. Sinauer Associates.

Sullivan, J. P., S. Lavoue, \& C. D. Hopkins. 2000. Molecular systematics of the African electric fishes (mormyroidea: teleostei) and a model for the evolution of their Electric organs. J. Experimental Biology. 203: 665-683.

Roni, P. \& T. P. Quinn. 1995. Geographic variation in size and age of North America chinook salmon. North America J. Fisheries Management 15: 325345.

Tanning, A. W. 1952: Experimental study of meristic characters in fishes. Biology Rev. Cambridge Phil. Society. 27: 169-193.

Thorpe, N. D. 1984. Cell Biology. John Wiley \& Sons Inc. New York.

Turan, C., E. Deniz, F. Turan, \& M. Ergüden. 2004. Genetic and morphologic structure of Liza abu (Heckel, 1843) populations from the Rivers Orontes, Euphrates, and Tigris. Turkey J.Vet Anim Sci. 28: 729-734.

Voris, H. K. 2000. Maps of pleitocence sea levels in SouthEast Asia, shorelines and time durations. J. Biogeography. 27:1153-1167. 